\title{
Quantitative Analysis of Apatite Formation on Titanium and Zirconia in a Simulated Body Fluid Solution Using the Quartz Crystal Microbalance Method
}

\author{
Eiji Yoshida and Tohru Hayakawa \\ Department of Dental Engineering, Tsurumi University School of Dental Medicine, 2-1-3 Tsurumi, Tsurumi-ku, \\ Yokohama 230-8501, Japan \\ Correspondence should be addressed to Eiji Yoshida; yoshida-e@tsurumi-u.ac.jp
}

Received 21 December 2016; Revised 9 March 2017; Accepted 21 March 2017; Published 2 April 2017

Academic Editor: Michele Iafisco

Copyright (c) 2017 Eiji Yoshida and Tohru Hayakawa. This is an open access article distributed under the Creative Commons Attribution License, which permits unrestricted use, distribution, and reproduction in any medium, provided the original work is properly cited.

\begin{abstract}
The bone-bonding ability of a material is evaluated by examining apatite formation on its surface in simulated body fluid (SBF). Partially stabilized zirconia $\left(\mathrm{ZrO}_{2}\right)$ is currently attractive as an alternative to titanium (Ti) implants; however, no quantitative analysis of apatite formation between $\mathrm{Ti}$ and $\mathrm{ZrO}_{2}$ in SBF has been reported. In the present study, we quantitatively evaluated apatite formation onto $\mathrm{Ti}$ or $\mathrm{ZrO}_{2}$ in SBF using the $27 \mathrm{MHz}$ quartz crystal microbalance method (QCM). In the QCM measurements, apatite formation was detected as a frequency decrease in the Ti or $\mathrm{ZrO}_{2}$ sensor. Frequency decreases were observed at around 1 hour for $\mathrm{Ti}$ and at around 2 hours for the $\mathrm{ZrO}_{2}$ sensor after the injection of SBF. This revealed that the Ti sensor showed faster apatite formation than $\mathrm{ZrO}_{2}$. There was no significant difference in the amounts of apatite formation between the Ti and $\mathrm{ZrO}$ sensors after 24 hours of apatite formation in SBF. In conclusion, the present quantitative study using QCM revealed that apatite formation on the Ti surface in the SBF was obviously faster than that on the $\mathrm{ZrO}_{2}$ surface. Faster apatite formation may predict faster initiation of bone formation on Ti compared with $\mathrm{ZrO}_{2}$.
\end{abstract}

\section{Introduction}

For evaluating the biocompatibility or tissue responses of biomaterials in hard tissue, in vitro simulation methods using simulated body fluid have been postulated in addition to animal experiments and/or cell assays. Kokubo [1] reported that the essential requirement for a biomaterial to bind to living bone is the formation of bone-like apatite on its surface when implanted in the living body. They proposed that in vivo apatite formation could be reproduced after the immersion of a material in a SBF, in which ion concentrations are nearly equal to human blood plasma [1]. There are numerous studies on the effectiveness of SBF immersion experiments by Kokubo and his colleagues, and the in vivo bioactivity, namely, osteoconductivity, of biomaterials is precisely mirrored by the in vitro apatite-forming ability in SBF [2-4]. In addition to Kokubo's SBF, Hanawa et al. $[5,6]$ proposed Hanks' balanced salt solution (HBSS) without organic species at $\mathrm{pH} 7.4$ as an SBF and found apatite formation on a Ti surface in HBSS. Our group [7-10] examined apatite deposition on the surface of modified Ti materials, such as thin-apatite-coated or DNA-coated Ti materials, after immersion in SBF and found that better apatite deposition on the biomaterials in HBSS corresponded with better in vivo bone formation. Thus, an SBF immersion experiment is useful for evaluating biocompatibility or tissue responses of biomaterials for hard tissue, which can reduce the number of animals used and the duration of animal experiments.

Recently, yttria-stabilized tetragonal zirconia polycrystal, which is known as partially stabilized zirconia $\left(\mathrm{ZrO}_{2}\right)$, attracted attention as an alternative to titanium as an implant material that overcomes the shortcomings of titanium implants such as the dark grayish color [11] and metal sensitivity [12]. There are various results regarding bone response to $\mathrm{ZrO}_{2}$ implants. Some report that $\mathrm{ZrO}_{2}$ ceramic implants show similar or better behavior than Ti implants in 
bone response [13-15]. In contrast, it was reported that the removal torque of $\mathrm{Ti}$ implants was significantly higher than that of $\mathrm{ZrO}_{2}$ after implantation into the femurs of rabbits and that the bone formation of $\mathrm{ZrO}_{2}$ seemed to proceed more slowly than roughened $\mathrm{Ti}[16,17]$. However, there are no quantitative analyses for apatite formation between $\mathrm{Ti}$ and $\mathrm{ZrO}_{2}$ in SBF.

The quartz crystal microbalance (QCM) technique is a straightforward method for detecting the adsorption or precipitation of biomolecules onto a material surface by measuring differences in the oscillating frequency of the quartz cell [18]. The adsorption or precipitation of biomolecules onto the surface of the oscillating quartz crystal causes the oscillation frequency to decrease in relation to the amount of biomolecules bound to the crystal surface. In the QCM measurements, apatite formation was detected as a frequency decrease in $\mathrm{Ti}$ or $\mathrm{ZrO}_{2}$ sensor in SBF.

There are a few reports on monitoring apatite formation on a material in SBF using the QCM method. Tanahashi et al. [19] reported on apatite formation on gold sensors in SBF. They assessed the process of apatite formation in two steps, namely, the initial nucleation step with glass powder and the crystal growth step in the absence of glass powder using QCM. Other QCM studies suggested that negatively charged surfaces of a self-assembled monolayer or nanocrystalline $\mathrm{TiO}_{2}$ coating induced apatite formation in SBF [20-22].

In the present study, we aimed to investigate apatite formation onto Ti or $\mathrm{ZrO}_{2}$ quantitatively in SBF using a $27 \mathrm{MHz}$ QCM, which enabled measurements with high sensitivity and low noise $[23,24]$. The Ti and $\mathrm{ZrO}_{2}$ sensor were characterized by contact angle measurement and X-ray photoelectron spectroscope (XPS) analysis, and the obtained apatite crystals were identified by scanning electron microscopy (SEM) and XPS. The null hypothesis tested was that the difference in the materials $\mathrm{Ti}$ and $\mathrm{ZrO}_{2}$ did not influence apatite formation in SBF.

\section{Materials and Methods}

2.1. QCM Apparatus and Sensors. A 27-MHz QCM (AT cut shear mode, AFFINIX QN $\mu$, ULVAC Co., Ltd., Tokyo, Japan) with a $500 \mu \mathrm{L}$ cell was used. The temperature was maintained at $25 \pm 1^{\circ} \mathrm{C}$, and the SBF solution in the cells was not stirred during the measurements.

$\mathrm{Ti}$ and $\mathrm{ZrO}_{2}$ sensors were used. Each sensor was prepared by the sputter coating of each material on an Au electrode [25]. Briefly, Ti or zirconium disks (Quartz 4N, ULVAC, Inc., Kanagawa, Japan) were used as a target, and the deposition of each material was performed using sputtering deposition equipment (CS200, ULVAC, Inc., Kanagawa, Japan). Ti sputtering was performed under argon gas, and zirconium sputtering under oxygen gas to deposit $\mathrm{ZrO}_{2}$. The film thickness of $\mathrm{Ti}$ and $\mathrm{ZrO}_{2}$ sensor was measured by the step profiler (Dektak 150, Veeco Instruments, Inc., USA) and the surface roughness of each sensor was measured by atomic force microscope (AFM: Nanosurf Easyscan 2, Nanosurf, AG, Switzerland) according to the previous report [25]. AFM measurements were carried out by the tapping mode using tapping mode silicon probes (Tap190AL-G, force contact $48 \mathrm{~N} / \mathrm{m}$, Budget sensors, Bulgaria) with resonance frequencies of approximately $190 \mathrm{kHz}$ in an area with $2 \times$ $2 \mu \mathrm{m}^{2}$. Each sensor was irradiated by ultraviolet radiation (BioForce Nanosciences Holdings Inc., USA) for 20 minutes before QCM measurement.

2.2. Measurements of Apatite Precipitation by QCM Method within SBF Solution. Hanks' balanced salt solution (HBSS) without organic species was prepared as the SBF. The ion concentrations of HBSS are as follows: $\mathrm{Na}^{+}: 142, \mathrm{~K}^{+}: 5.81$, $\mathrm{Mg}^{2+}: 0.811, \mathrm{Ca}^{2+}: 1.26, \mathrm{Cl}^{-}: 145, \mathrm{HCO}_{3}{ }^{-}: 4.17, \mathrm{HPO}_{4}{ }^{2-}: 0.778$, and $\mathrm{SO}_{4}{ }^{2-}: 0.811 \mathrm{mmol} / \mathrm{L}$.

A cell with a Ti or $\mathrm{ZrO}_{2}$ sensor was set in the QCM apparatus. After stabilization of the frequency, a $500 \mu \mathrm{L}$ SBF solution was injected into the cell. The frequency decrease was monitored until 24 hours after injection of the SBF solution. The amount of apatite formation onto each surface at 24 hours after SBF injection was calculated by Sauerbrey's equation [26]. A frequency decrease of $1 \mathrm{~Hz}$ corresponds to a mass change of $0.61 \pm 0.1 \mathrm{ng} / \mathrm{cm}^{2}$ on the sensor in a $27 \mathrm{MHz}$ QCM system. By curve fitting for the $\Delta F$ curve against time, the apparent reaction rate, Kobs, in the following equation was obtained. $\Delta F_{\infty}$ is the frequency shift at infinite time. Three runs of QCM measurements were performed during a 24-hour period.

$$
\Delta F_{t}=\Delta F_{\infty}\left(1-e^{- \text {Kobs } \cdot t}\right) .
$$

Before the SBF experiment, the solubility of Ti and $\mathrm{ZrO}_{2}$ was checked by detecting frequency change in ultrapure water instead of SBF and no dissolution of $\mathrm{Ti}$ and $\mathrm{ZrO}_{2}$ during the 24 hours was confirmed.

2.3. Contact Angle Measurements of Ti and $\mathrm{ZrO}_{2}$ Sensors. The contact angles of Ti and $\mathrm{ZrO}_{2}$ sensor surfaces with respect to double-distilled water were measured using a contact angle meter (DMe-201, Kyowa Interface Science Co., Ltd., Tokyo, Japan) after the ultraviolet irradiation of each sensor. The water drop volume was maintained at $0.5 \mu \mathrm{L}$, and three measurements of 15 seconds each were made for each surface type. The measurements were performed at the same room temperature and humidity.

2.4. SEM Observation. After 24 hours of apatite formation in $\mathrm{SBF}$, each sensor was cleaned with distilled water and was naturally dried in the atmosphere. After ion coating with gold, the morphology of the crystals was observed using a SEM (JSM-5600LV, JEOL, Tokyo, Japan) at an accelerating voltage of $10 \mathrm{kV}$.

2.5. XPS Analysis. Surface elemental analyses of each sensor before and after apatite formation were performed using an X-ray photoelectron spectroscope (XPS, KRATOS AXIS Nova, Shimadzu Corp., Kyoto, Japan) equipped with an Alk $\alpha$ $\mathrm{X}$-ray source operated at $300 \mathrm{~W}$. After 24 hours of apatite formation in SBF, each sensor was cleaned with distilled water and was naturally dried in the atmosphere. The Ti2p, 
TABLE 1: Contact angle measurements of Ti and $\mathrm{ZrO}_{2}$ sensors (mean $\pm \mathrm{SD} n=3)$.

\begin{tabular}{lcc}
\hline Samples & $\mathrm{Ti}$ & $\mathrm{ZrO}_{2}$ \\
\hline Contact angle $\left(^{\circ}\right)$ & $5.8(0.9)^{\mathrm{a}}$ & $5.3(0.9)^{\mathrm{a}}$
\end{tabular}

The same letters denote no significant difference $(p>0.05)$.

Zr3d, and O1s peaks of each sensor were analyzed before apatite formation, and the Ca2p, P2p, and O1s peaks of apatite crystals on each sensor were analyzed after apatite formation.

2.6. Statistical Analyses. Significant differences were determined using statistical analysis software (GraphPad Prism, GraphPad Software Inc., San Diego, CA, USA). Statistical significance was set at $p<0.05$. Nonpaired $t$-test was employed to compare data obtained from contact angle measurements and in QCM measurements.

\section{Results}

3.1. Characterization of QCM Sensors. The film thickness of $\mathrm{Ti}$ and $\mathrm{ZrO}_{2}$ sensor was approximately 150 and $110 \mathrm{~nm}$, respectively, and the surface roughness of each sensor was approximately $4 \sim 5 \mathrm{~nm}$ [25]. The contact angles of the Ti and $\mathrm{ZrO}_{2}$ sensors are shown in Table 1 . There was no significant difference in the contact angle between the Ti and $\mathrm{ZrO}_{2}$ sensors ( $p>0.05$ ), and both showed hydrophilic surfaces. XPS analyses of the Ti and $\mathrm{ZrO}_{2}$ sensors are shown in Figure 1. Wide spectra indicated the presence of Ti and $\mathrm{Zr} 3 \mathrm{~d}$ for Ti and $\mathrm{ZrO}_{2}$ sensor as shown in Figures 1(a) and 1(d), respectively. Ols peak was identified for both $\mathrm{Ti}$ and $\mathrm{ZrO}_{2}$ sensors. Higher resolution Ti2p spectrum showed the presence of Ti2 $\mathrm{p}_{3 / 2}$ at $459.0 \mathrm{eV}$ and Ti2 $\mathrm{p}_{1 / 2}$ peak at $464.8 \mathrm{eV}$ [27]. The Ols peak at $530.6 \mathrm{eV}$ and $532.1 \mathrm{eV}$ as shown in Figure 1(c) corresponded to the bulk oxygen in titanium dioxide and basic terminal $\mathrm{OH}$ (Ti-OH), respectively $[28,29]$. For the $\mathrm{ZrO}_{2}$ sensor, higher resolution spectrum identified the presence of $\mathrm{Zr}_{3} \mathrm{~d}_{5 / 2}$ at $182.1 \mathrm{eV}$ and $\mathrm{Zr}_{3 / 2}$ at $184.5 \mathrm{eV}$ as shown in Figure 1(d) [30]. Higher resolution O1s spectrum showed two O1s peaks as shown in Figure 1(f). O1s peak at $530.4 \mathrm{eV}$ could be attributed to the bulk oxygen in $\mathrm{ZrO}_{2}$ and that at $531.8 \mathrm{eV}$ may be the oxygen of $\mathrm{Zr}-\mathrm{OH}$ [31].

3.2. QCM Measurements. The frequency curves for the Ti and $\mathrm{ZrO}_{2}$ sensors are shown in Figure 2. No apparent frequency decrease was observed at the initial stage. Distinct frequency decrease was observed at around 1 hour for the Ti sensor and at around 2 hours for the $\mathrm{ZrO}_{2}$ sensor, after the injection of SBF (arrow in Figure 2). Thus, the frequency curves were separated into two stages: the stable initial stage and the apatite formation stage.

Table 2 lists the time for the stable initial stage before frequency decrease (apatite formation). The $\mathrm{ZrO}_{2}$ sensor showed a significantly longer time for the initial stage than the Ti sensor $(p<0.05)$. The amounts of apatite formation on $\mathrm{Ti}$ and $\mathrm{ZrO}_{2} 24$ hours after SBF injection are shown in
TABLE 2: Time at which frequency began to decrease (mean \pm SD $n=3)$.

\begin{tabular}{lcc}
\hline Samples & $\mathrm{Ti}$ & $\mathrm{ZrO}_{2}$ \\
\hline Time (min.) & $52.0(31.7)^{\mathrm{a}}$ & $115.4(27.3)^{\mathrm{b}}$ \\
\hline
\end{tabular}

The different letters denote significant difference $(p<0.05)$.

Figure 3. There was no significant difference in the amounts of apatite formation between the $\mathrm{Ti}$ and $\mathrm{ZrO}_{2}$ sensors $(p>$ $0.05)$. Figure 4 shows the apparent reaction rate for apatite formation during the apatite-forming stage until 24 hours. No significant difference existed between the Ti and $\mathrm{ZrO}_{2}$ sensors $(p>0.05)$.

3.3. SEM Observation of Apatite Crystals. Figure 5 shows the SEM pictures of apatite crystals on each sensor after 24 hours of SBF immersion. It was confirmed that apatite crystals were randomly precipitated on each sensor (Figures 5(a) and 5(c)). Apatite crystals with a diameter of approximately $500 \mathrm{~nm}$ were sparsely observed on the $\mathrm{Ti}$ and $\mathrm{ZrO}_{2}$ sensors (Figures $5(b)$ and 5(d)). Both showed similar morphologies of apatite crystals.

3.4. XPS Measurements of Apatite Crystals. The Ca2p, P2p, and O1s peaks of the apatite crystals were identified on each sensor as shown in Figure 6. Higher resolution of Ca2p spectra showed the presence of $\mathrm{Ca} 2 \mathrm{p}_{1 / 2}$ at $347.3 \mathrm{eV}$ and $\mathrm{Ca} 2 \mathrm{p}_{3 / 2}$ at $351.0 \mathrm{eV}$ as shown in Figures 6(b) and 6(f) [32]. Figures $6(\mathrm{c})$ and $6(\mathrm{~g})$ show the P2p peak at $133.3 \mathrm{eV}$ [32]. Figures 6(d) and 6(f) show the Ols peak at $532.7 \mathrm{eV}$ [33]. The $\mathrm{Ca} / \mathrm{P}$ atomic ratio of apatite crystals obtained by XPS measurement was approximately 1.46 , which was relatively smaller than that of stoichiometric hydroxyapatite.

\section{Discussion}

In the present study, we evaluated apatite formation on $\mathrm{Ti}$ and $\mathrm{ZrO}_{2}$ surfaces in SBF solution using the QCM method. The study revealed that apatite formation on Ti was significantly faster than that on $\mathrm{ZrO}_{2}$. Therefore, the null hypothesis was rejected.

The surface charge of a substrate plays an important role in the reaction of the substrate in an aqueous solution. Some researchers prepared negatively and positively charged surfaces using the SAM technique and monitored apatite formation in an SBF solution using the QCM method [20, 21]. They found that negatively charged surfaces with $\mathrm{PO}_{4} \mathrm{H}_{2}$ or $\mathrm{COOH}$ groups showed more progressed apatite formation than positively charged surfaces with $\mathrm{NH}_{2}$ groups. The apatite formation was initiated by the calcium ion adsorption on negatively charged surfaces, and consequently phosphate ions bound to the adsorbed calcium ions. With the increase in immersion time, a large amount of calcium ions and phosphate ions was attracted to the surface to form apatite crystals.

In our previous study, the apparent zeta potentials of $\mathrm{Ti}$ and $\mathrm{ZrO}_{2}$ at $\mathrm{pH}=7.4$, which were measured by the streaming 


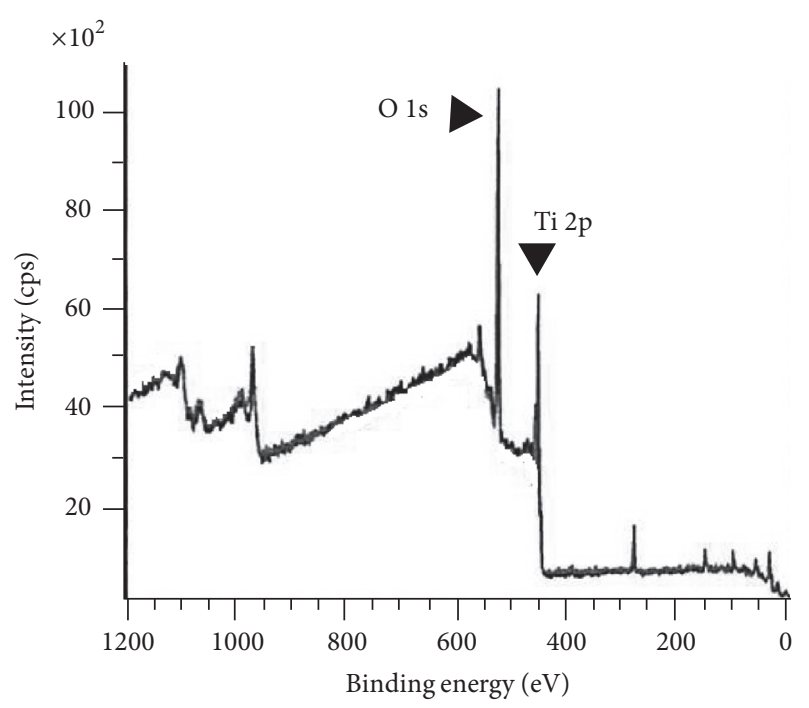

(a)

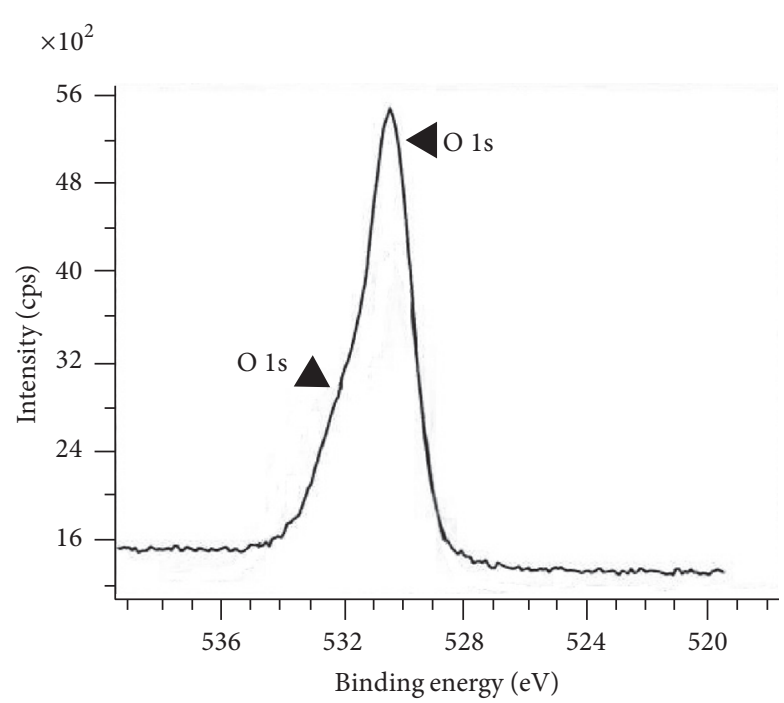

(c)

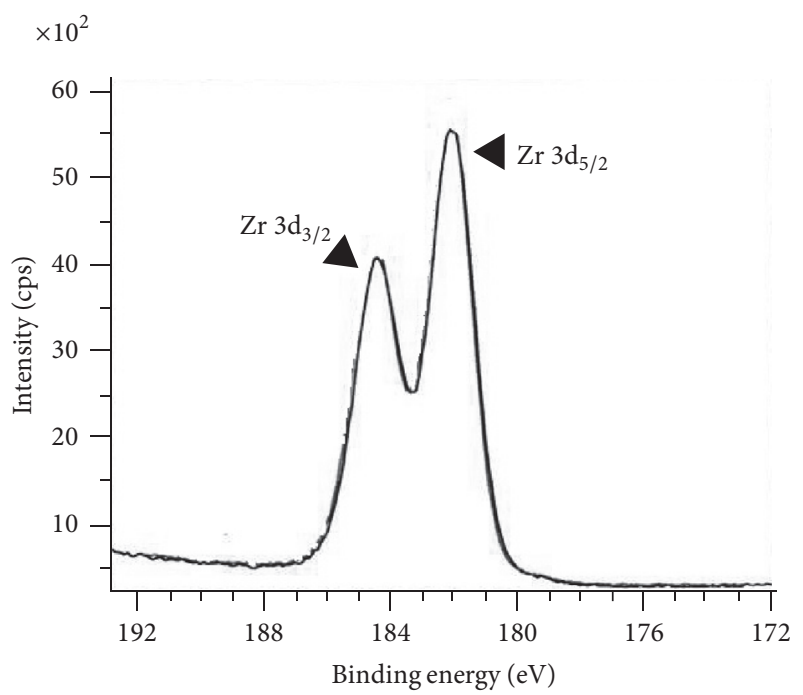

(e)

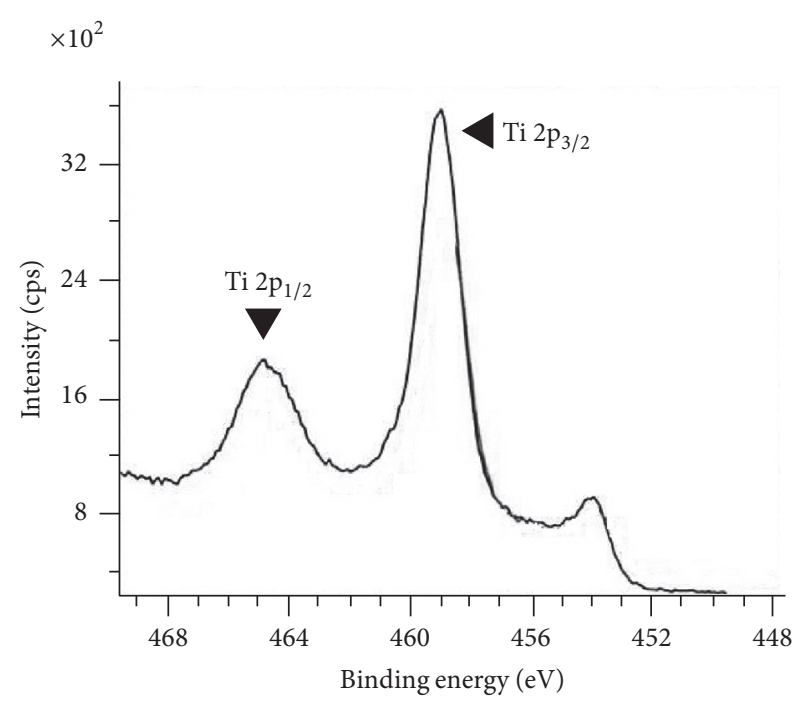

(b)

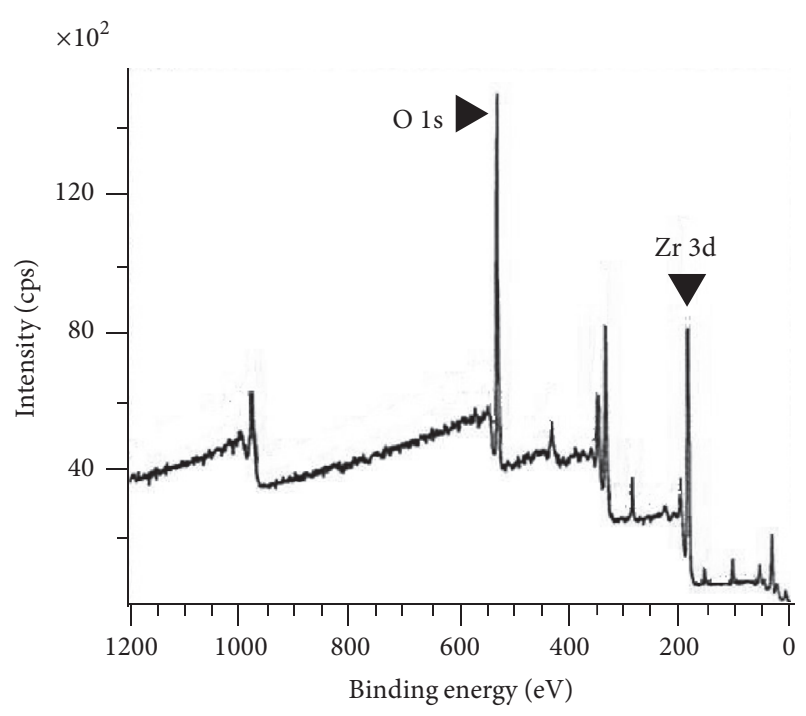

(d)

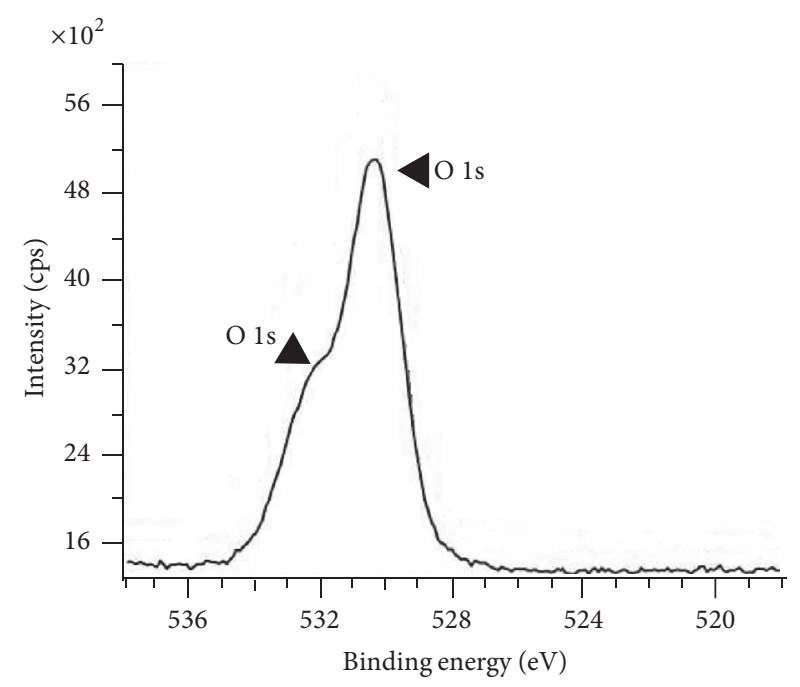

(f)

FIGURE 1: XPS analysis of Ti and $\mathrm{ZrO}_{2}$ sensors. (a) XPS spectrum of the Ti sensor, (b) higher resolution XPS spectrum of Ti2p of the Ti sensor, (c) higher resolution XPS spectrum of O1s of the Ti sensor, (d) XPS spectrum of the $\mathrm{ZrO}_{2}$ sensor, (e) higher resolution XPS spectrum of Zr3d of the $\mathrm{ZrO}_{2}$ sensor, and (f) higher resolution XPS spectrum of Ols of the $\mathrm{ZrO}_{2}$ sensor. 


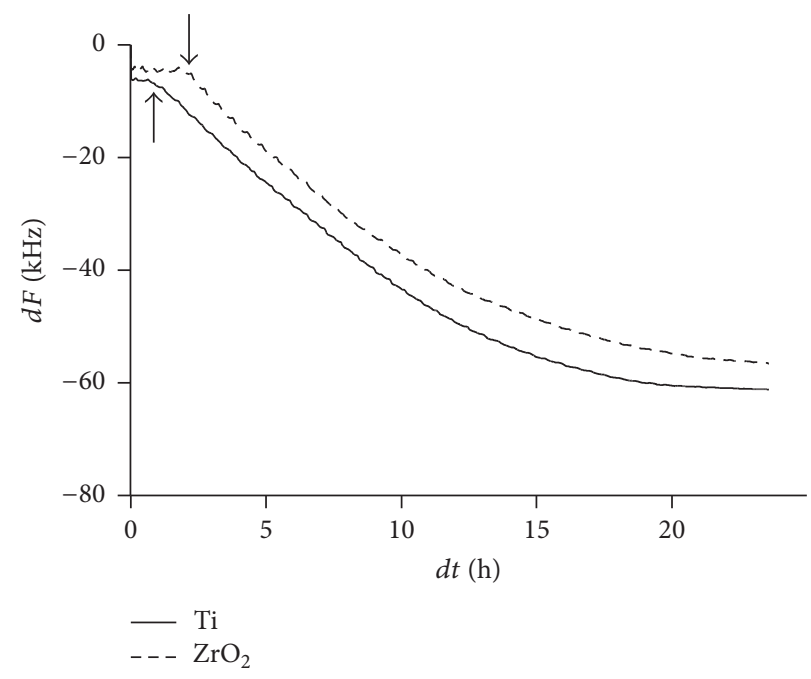

FIGURE 2: Frequency decrease curves for Ti and $\mathrm{ZrO}_{2}$ sensors in $\mathrm{SBF}$ solution. The arrows indicate initial stable time before frequency decrease on each sensor.

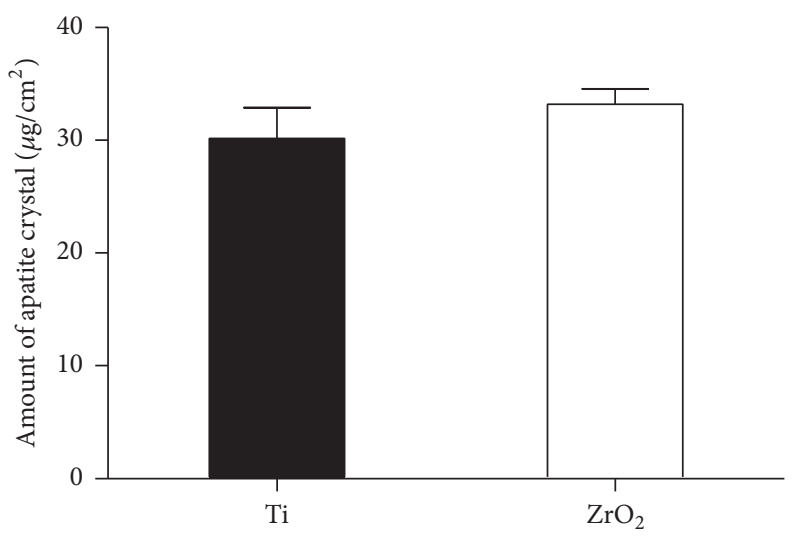

FIGURE 3: Estimated amounts of apatite formation on Ti and $\mathrm{ZrO}_{2} 24$ hours after SBF injection. No significant difference between Ti and $\mathrm{ZrO}_{2}(p>0.05)$.

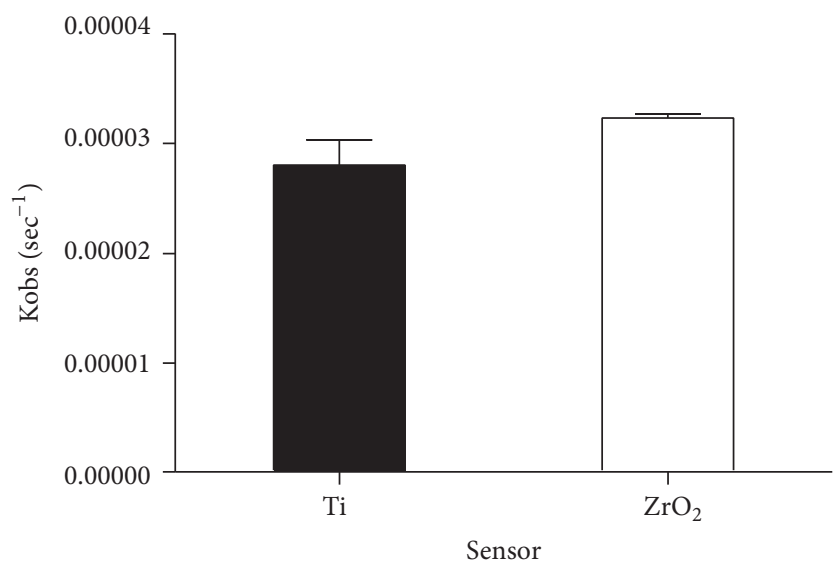

FIGURE 4: The apparent reaction rate for apatite formation. No significant difference between $\mathrm{Ti}$ and $\mathrm{ZrO}_{2}(p>0.05)$. 


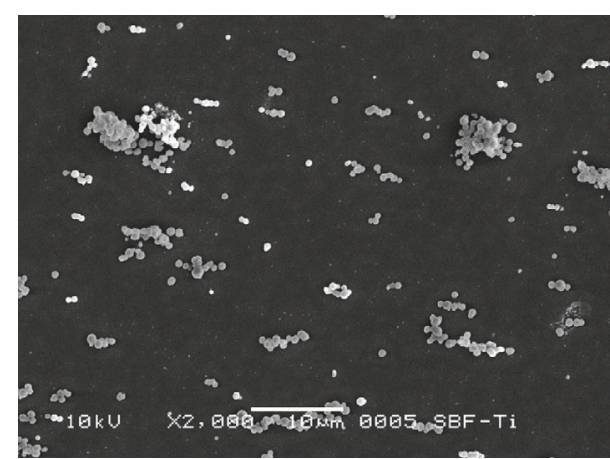

(a)

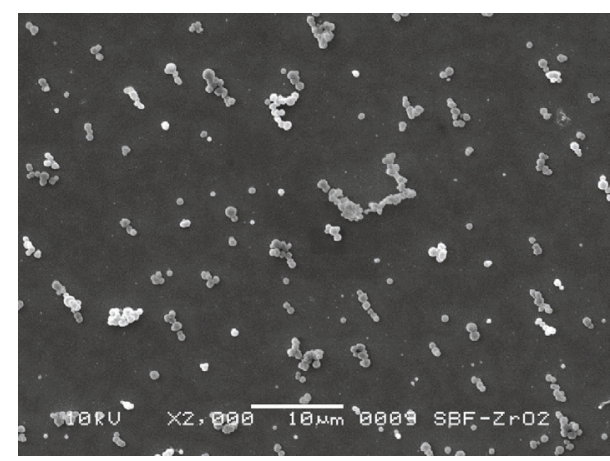

(c)

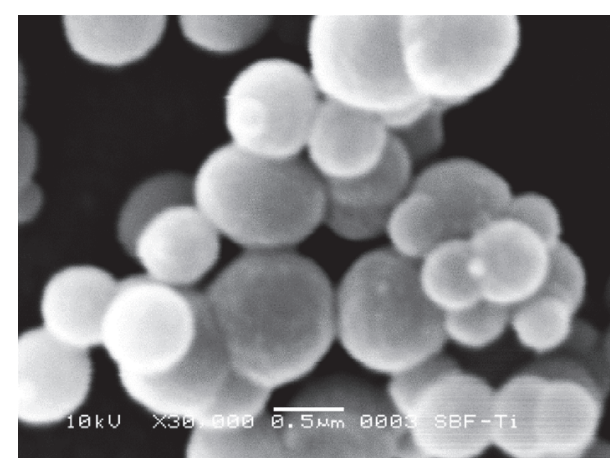

(b)

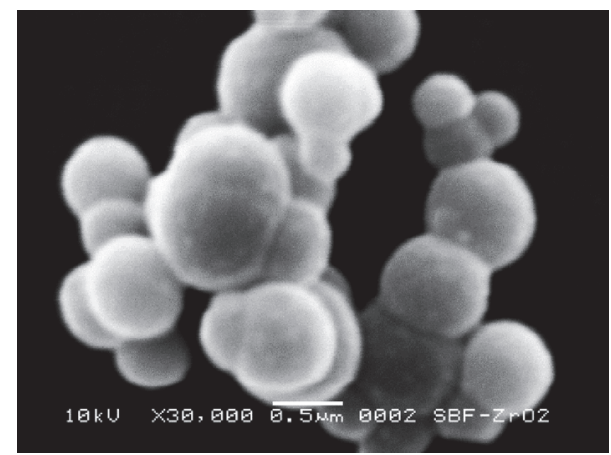

(d)

FIGURE 5: SEM pictures of apatite crystals on each sensor after 24 hours of SBF immersion. (a, c) Apatite crystals on Ti sensor with lower and higher magnification. (b, d) Apatite crystals on $\mathrm{ZrO}_{2}$ sensor with lower and higher magnification.

potential technique, were reported to be approximately -87 and $-43 \mathrm{mV}$, respectively [25]. This means that both $\mathrm{Ti}$ and $\mathrm{ZrO}_{2}$ surfaces were negatively charged, and $\mathrm{Ti}$ was more negatively charged than $\mathrm{ZrO}_{2}$. Thus, it is presumed that the faster apatite formation on $\mathrm{Ti}$ was due to the more negatively charged surface. The present results accorded with previous reports [20-22]; namely, a higher number of calcium ions in the SBF were initially attracted to the more negatively charged Ti surface. Subsequently, phosphate ions and the calcium ions in the SBF combined, and apatite nuclei formed. Faster apatite formation may predict faster initiation of bone formation. The amounts of apatite formation between $\mathrm{Ti}$ and $\mathrm{ZrO}_{2}$ were not significantly different for the 24 hours of SBF immersion. The difference in surface charge only influenced the initial nucleation stage not the apatite formation stage.

Besides apatite formation, protein behaviors such as adsorption, proliferation, and differentiation influence the achievement of bone formation. Kusakawa et al. [34] studied protein adsorption onto $\mathrm{Ti}$ and $\mathrm{ZrO}_{2}$ using the QCM method. It was reported that $\mathrm{Ti}$ showed greater adsorption of fibronectin, cell adhesive protein, and albumin, a cell adhesion-inhibiting protein. Monitoring apatite formation and protein behaviors is needed to analyze the level of bone formation.

\section{Conclusion}

This paper examined apatite formation on $\mathrm{Ti}$ and $\mathrm{ZrO}_{2}$ in SBF using the $27 \mathrm{MHz}$ QCM method. The obtained apatite crystals were characterized by scanning electron microscopy (SEM) and X-ray photoelectron spectroscope (XPS) analysis. It was found that the apatite formation on the $\mathrm{Ti}$ surface in the SBF was clearly faster than that on the $\mathrm{ZrO}_{2}$ surface. This was due to the more negatively charged Ti surface compared with $\mathrm{ZrO}_{2}$. No significant difference existed in the amounts of apatite formation, the size of apatite crystals, and the $\mathrm{Ca} / \mathrm{P}$ atomic ratio of apatite crystals between the $\mathrm{Ti}$ and $\mathrm{ZrO}_{2}$ sensors. Faster apatite formation may predict faster initiation of bone formation in Ti compared with $\mathrm{ZrO}_{2}$.

\section{Conflicts of Interest}

The authors declare that they have no conflicts of interest.

\section{Acknowledgments}

The authors are grateful to Professor Masao Yoshinari in the Division of Oral Implants Research, Oral Health Science Center, Tokyo Dental College, for the XPS analysis. This study was supported in part by the Japan Society for the 


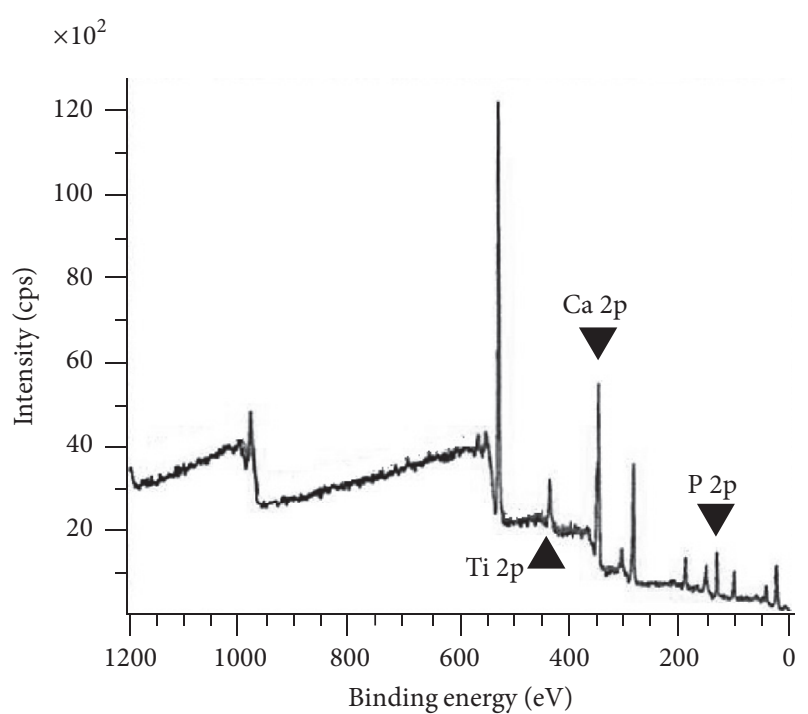

(a)

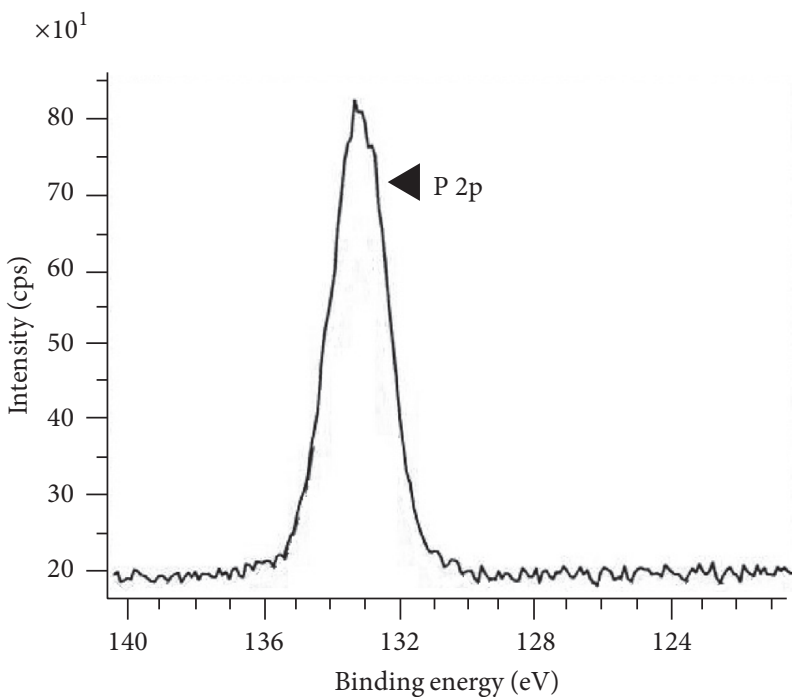

(c)

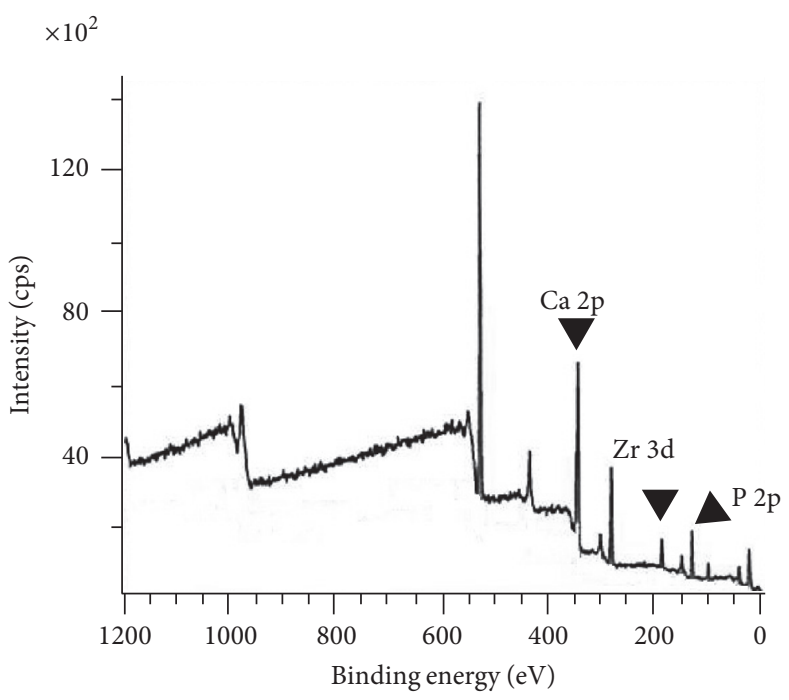

(e)

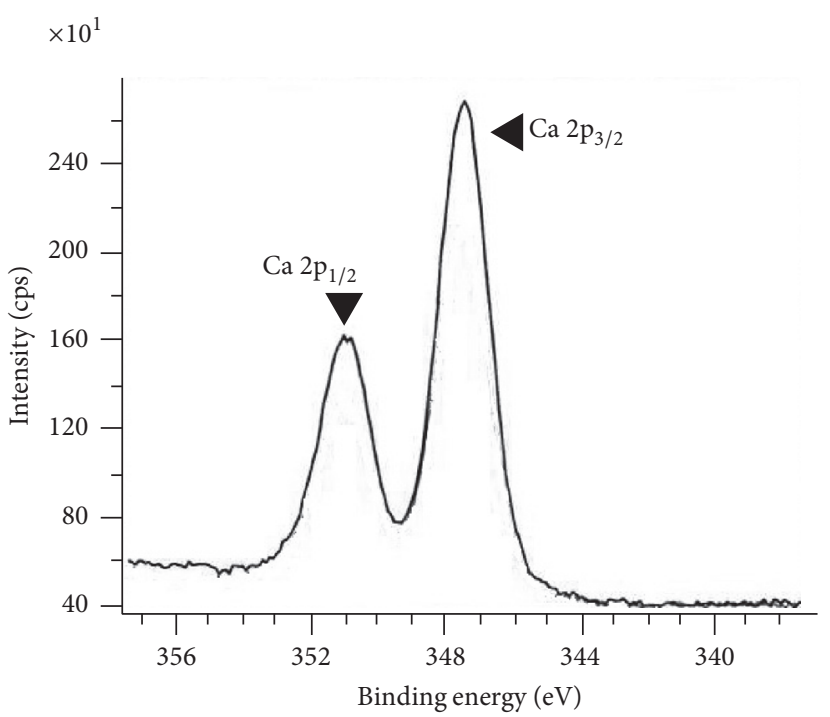

(b)

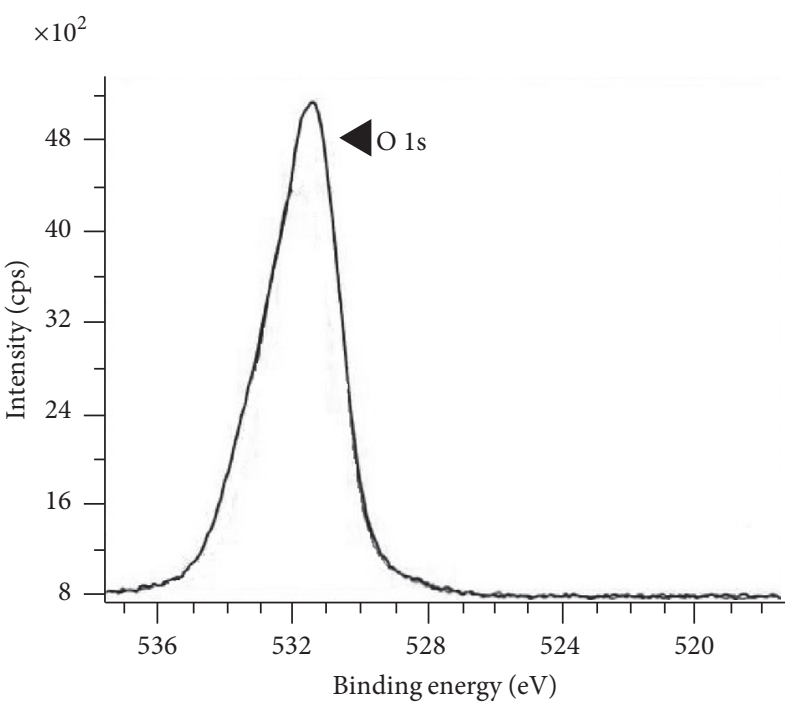

(d)

$$
\times 10^{2}
$$

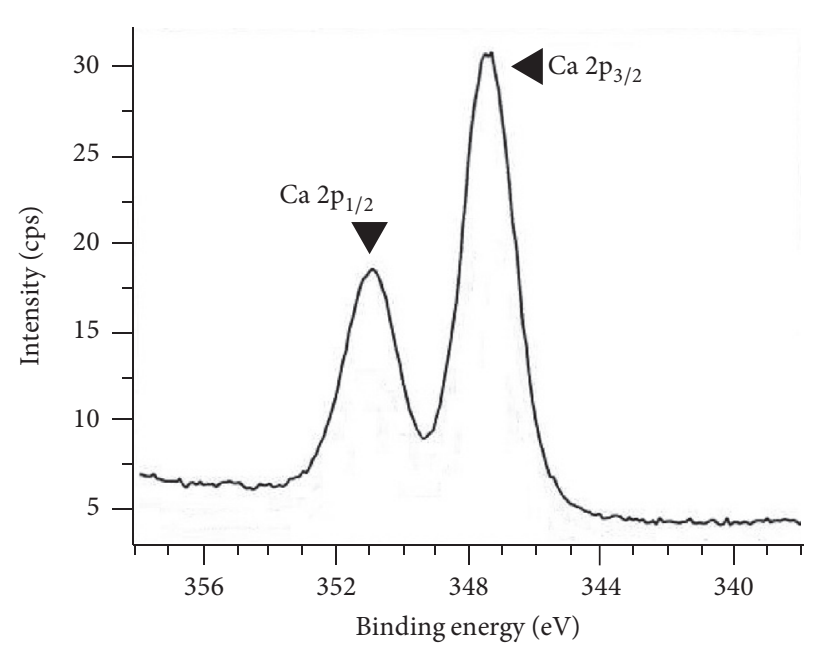

(f)

FIGURE 6: Continued. 


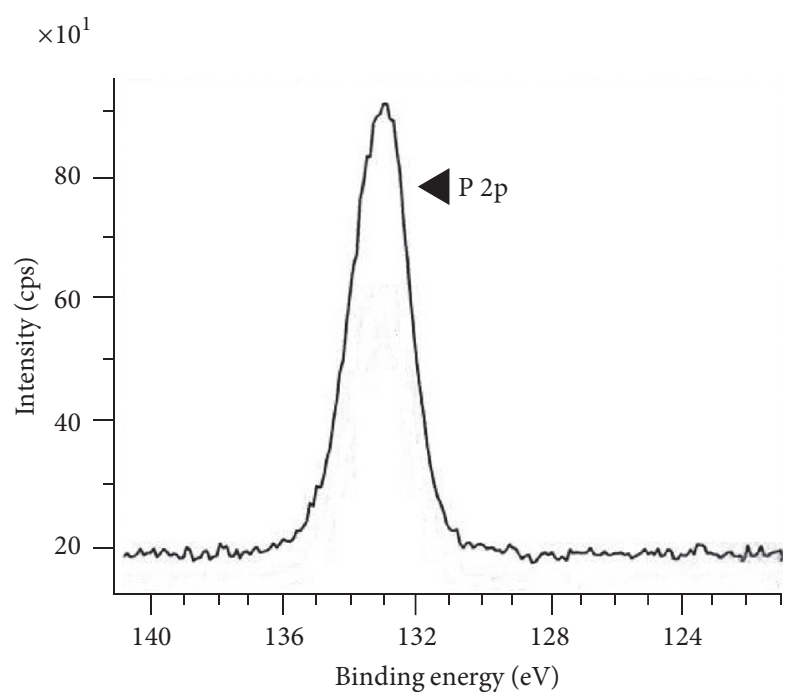

(g)

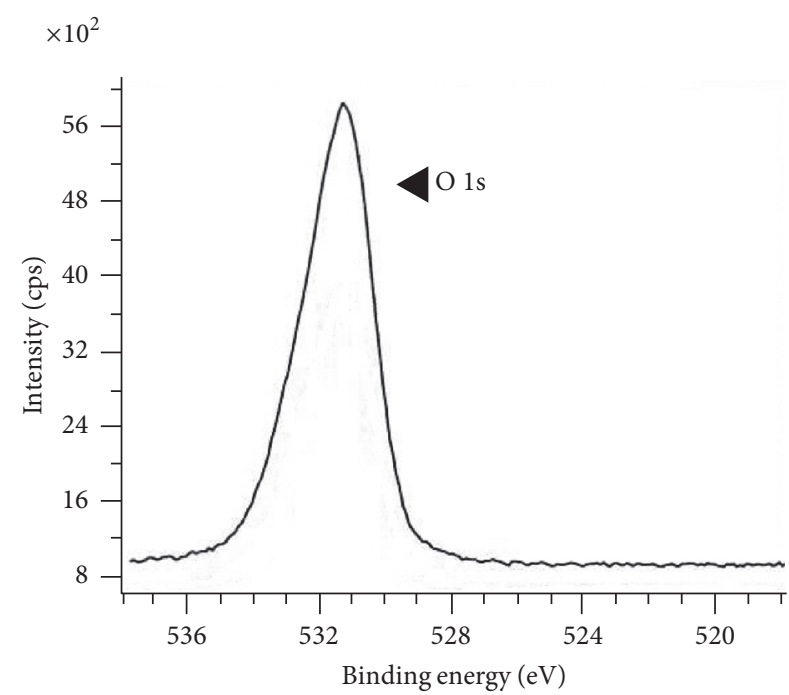

(h)

FIGURE 6: XPS measurements of apatite crystals. (a) XPS spectrum of apatite crystals of the Ti sensor, (b) higher resolution XPS spectrum of Ca2p of Ti sensor apatite crystals, (c) higher resolution XPS spectrum of P2p of Ti sensor apatite crystals, (d) higher resolution XPS spectrum of Ols of Ti sensor apatite crystals, (e) XPS spectrum of apatite crystals of $\mathrm{ZrO}_{2}$ sensor, (f) higher resolution XPS spectrum of Ca2p of ZrO sensor apatite crystals, (g) higher resolution XPS spectrum of $\mathrm{P} 2 \mathrm{p}$ of $\mathrm{ZrO}_{2}$ sensor apatite crystals, and (h) higher resolution XPS spectrum of $\mathrm{O} 1 \mathrm{~s}$ of $\mathrm{ZrO}_{2}$ sensor apatite crystals.

Promotion of Science, Grants-in-Aid for Young Scientists (B) (15K20490), by the MEXT-Supported Program for Strategic Research Foundation at Private Universities, 2015-2019.

\section{References}

[1] T. Kokubo, "Bioactive glass ceramics: properties and applications," Biomaterials, vol. 12, no. 2, pp. 155-163, 1991.

[2] S. Fujibayashi, M. Neo, H.-M. Kim, T. Kokubo, and T. Nakamura, "A comparative study between in vivo bone ingrowth and in vitro apatite formation on $\mathrm{Na}_{2} \mathrm{O}-\mathrm{CaO}-\mathrm{SiO}_{2}$ glasses," Biomaterials, vol. 24, no. 8, pp. 1349-1356, 2003.

[3] T. Kokubo and H. Takadama, "How useful is SBF in predicting in vivo bone bioactivity?" Biomaterials, vol. 27, no. 15, pp. 29072915, 2006.

[4] S. Yamaguchi, H. Takadama, T. Matsushita, T. Nakamura, and T. Kokubo, "Preparation of bioactive Ti-15Zr-4Nb-4Ta alloy from $\mathrm{HCl}$ and heat treatments after an $\mathrm{NaOH}$ treatment," Journal of Biomedical Materials Research Part A, vol. 97, no. 2, pp. 135-144, 2011.

[5] T. Hanawa, K. Asami, and K. Asaoka, "Repassivation of titanium and surface oxide film regenerated in simulated bioliquid," Journal of Biomedical Materials Research, vol. 40, no. 4, pp. 530538, 1998.

[6] Y. Tsutsumi, D. Nishimura, H. Doi, N. Nomura, and T. Hanawa, "Difference in surface reactions between titanium and zirconium in Hanks' solution to elucidate mechanism of calcium phosphate formation on titanium using XPS and cathodic polarization," Materials Science and Engineering: C, vol. 29, no. 5, pp. 1702-1708, 2009.

[7] K. Takahashi, T. Hayakawa, H. Hara et al., "Properties of hydroxyapatite thin film prepared by molecular precursor method-calcium phosphate formation on apatite thin film in simulated body fluid," The Journal of the Japanese Society for Dental Materials and Devices, vol. 24, pp. 39-46, 2005.

[8] T. Hayakawa, K. Takahashi, H. Okada et al., "Effect of thin carbonate-containing apatite (CA) coating of titanium fiber mesh on trabecular bone response," Journal of Materials Science: Materials in Medicine, vol. 19, no. 5, pp. 2087-2096, 2008.

[9] S. Yasuoka, Y. Usukura, M. Fuse, H. Okada, T. Hayakawa, and T. Kato, "Stainless and titanium fibers as non-degradable threedimensional scaffolds for bone reconstruction," Journal of Hard Tissue Biology, vol. 23, no. 4, pp. 407-414, 2014.

[10] T. Sakurai, M. Yoshinari, T. Toyama, T. Hayakawa, and C. Ohkubo, "Effects of a multilayered DNA/protamine coating on titanium implants on bone responses," Journal of Biomedical Materials Research Part A, vol. 104, pp. 1500-1509, 2016.

[11] G. Heydecke, R. Kohal, and R. Gläser, "Optimal esthetics in single-tooth replacement with the re-implant system: a case report," The International Journal of Prosthodontics, vol. 12, no. 2, pp. 184-189, 1999.

[12] E. Valentine-Thon and H.-W. Schiwara, "Validity of MELISA for metal sensitivity testing," Neuroendocrinology Letters, vol. 24, no. 1-2, pp. 57-64, 2003.

[13] R. Depprich, H. Zipprich, M. Ommerborn et al., "Osseointegration of zirconia implants compared with titanium: an in vivo study," Head \& Face Medicine, vol. 4, no. 1, article 30, 2008.

[14] H. J. Wenz, J. Bartsch, S. Wolfart, and M. Kern, "Osseointegration and clinical success of zirconia dental implants: a systematic review," The International Journal of Prosthodontics, vol. 21, no. 1, pp. 27-36, 2008.

[15] A. Apratim, P. Eachempati, K. K. Krishnappa Salian, V. Singh, S. Chhabra, and S. Shah, "Zirconia in dental implantology: a review," Journal of International Society of Preventive and Community Dentistry, vol. 5, no. 3, pp. 147-156, 2015.

[16] O. Hoffmann, N. Angelov, G.-G. Zafiropoulos, and S. Andreana, "Osseointegration of zirconia implants with different surface 
characteristics: an evaluation in rabbits," The International Journal of Oral \& Maxillofacial Implants, vol. 27, no. 2, pp. 352358, 2012.

[17] R. J. Kohal, M. Bächle, W. Att et al., "Osteoblast and bone tissue response to surface modified zirconia and titanium implant materials," Dental Materials, vol. 29, no. 7, pp. 763-776, 2013.

[18] B. S. Murray and C. Deshaires, "Monitoring protein fouling of metal surfaces via a quartz crystal microbalance," Journal of Colloid and Interface Science, vol. 227, no. 1, pp. 32-41, 2000.

[19] M. Tanahashi, T. Kokubo, and T. Matsuda, "Quantitative assessment of apatite formation via a biomimetic method using quartz crystal microbalance," Journal of Biomedical Materials Research, vol. 31, no. 2, pp. 243-249, 1996.

[20] M. Tanahashi and T. Matsuda, "Surface functional group dependence on apatite formation on self-assembled monolayers in a simulated body fluid," Journal of Biomedical Materials Research, vol. 34, no. 3, pp. 305-315, 1997.

[21] P. Zhu, Y. Masuda, T. Yonezawa, and K. Koumoto, "Investigation of apatite deposition onto charged surfaces in aqueous solutions using a quartz-crystal microbalance," Journal of the American Ceramic Society, vol. 86, no. 5, pp. 782-790, 2003.

[22] Z. Yang, S. Si, X. Zeng, C. Zhang, and H. Dai, "Mechanism and kinetics of apatite formation on nanocrystalline $\mathrm{TiO}_{2}$ coatings: a quartz crystal microbalance study," Acta Biomaterialia, vol. 4, no. 3, pp. 560-568, 2008.

[23] H. Furusawa, H. Takano, and Y. Okahata, "Transient kinetic studies of $\mathrm{pH}$-dependent hydrolyses by exo-type carboxypeptidase P on a $27-\mathrm{MHz}$ quartz crystal microbalance," Analytical Chemistry, vol. 80, no. 4, pp. 1005-1011, 2008.

[24] H. Yoshimine, T. Kojima, H. Furusawa, and Y. Okahata, "Small mass-change detectable quartz crystal microbalance and its application to enzymatic one-base elongation on DNA," Analytical Chemistry, vol. 83, no. 22, pp. 8741-8747, 2011.

[25] E. Yoshida and T. Hayakawa, "Adsorption analysis of lactoferrin to titanium, stainless steel, zirconia, and polymethyl methacrylate using the quartz crystal microbalance method," BioMed Research International, vol. 2016, Article ID 3961286, 7 pages, 2016.

[26] G. Sauerbrey, "Verwendung von Schwingquarzen zur Wägung dünner Schichten und zur Mikrowägung," Zeitschrift für Physik, vol. 155, no. 2, pp. 206-222, 1959.

[27] K. J. A. Raj, R. Shanmugam, R. Mahalakshmi, and B. Viswanathan, "XPS and IR spectral studies on the structure of phosphate and sulphate modified titania-a combined DFT and experimental study," Indian Journal of Chemistry, vol. 49, no. 1, pp. 9-17, 2010.

[28] K. E. Healy and P. Ducheyne, "Hydration and preferential molecular adsorption on titanium in vitro," Biomaterials, vol. 13, no. 8, pp. 553-561, 1992.

[29] D. E. MacDonald, B. Markovic, M. Allen, P. Somasundaran, and A. L. Boskey, "Surface analysis of human plasma fibronectin adsorbed to commercially pure titanium materials," Journal of Biomedical Materials Research, vol. 41, no. 1, pp. 120-130, 1998.

[30] A. Roustila, J. Chêne, and C. Séverac, "XPS study of hydrogen and oxygen interactions on the surface of the NiZr intermetallic compound," International Journal of Hydrogen Energy, vol. 32, no. 18, pp. 5026-5032, 2007.

[31] D. Barreca, G. A. Battiston, R. Gerbasi, E. Tondello, and P. Zanella, "Zirconium dioxide thin films characterized by XPS," Surface Science Spectra, vol. 7, no. 4, pp. 303-307, 2000.
[32] H. Takadama, H.-M. Kim, T. Kokubo, and T. Nakamura, "XPS study of the process of apatite formation on bioactive Ti-6Al-4V alloy in simulated body fluid," Science and Technology of Advanced Materials, vol. 2, no. 2, pp. 389-396, 2001.

[33] Y. W. Gu, K. A. Khor, and P. Cheang, "Bone-like apatite layer formation on hydroxyapatite prepared by spark plasma sintering (SPS)," Biomaterials, vol. 25, no. 18, pp. 4127-4134, 2004.

[34] Y. Kusakawa, E. Yoshida, and T. Hayakawa, "Protein adsorption to titanium and zirconia using a quartz crystal microbalance method," BioMed Research International, vol. 2017, Article ID 1521593, 8 pages, 2017. 

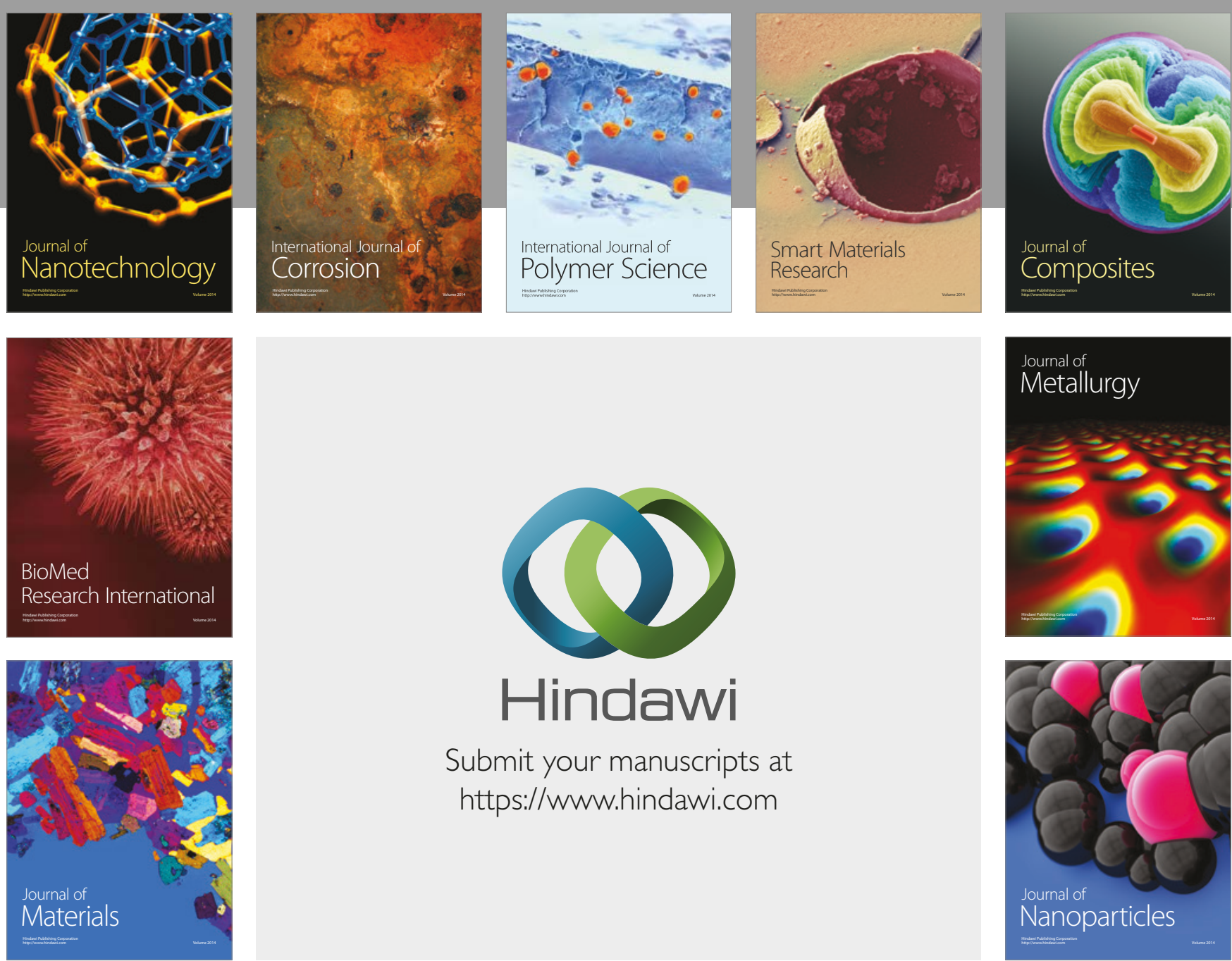

\section{Hindawi}

Submit your manuscripts at

https://www.hindawi.com
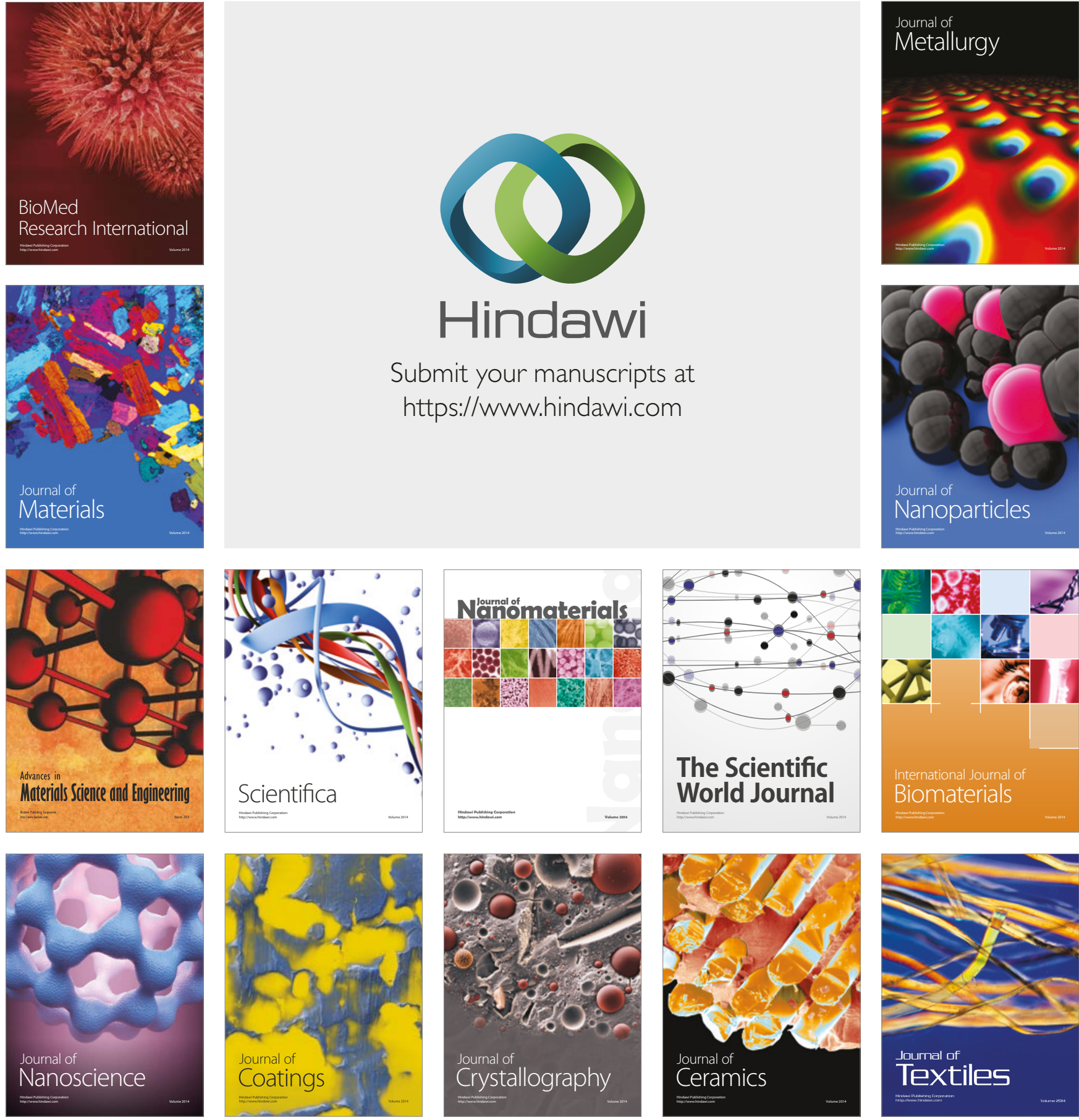

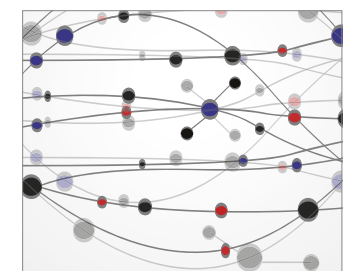

The Scientific World Journal
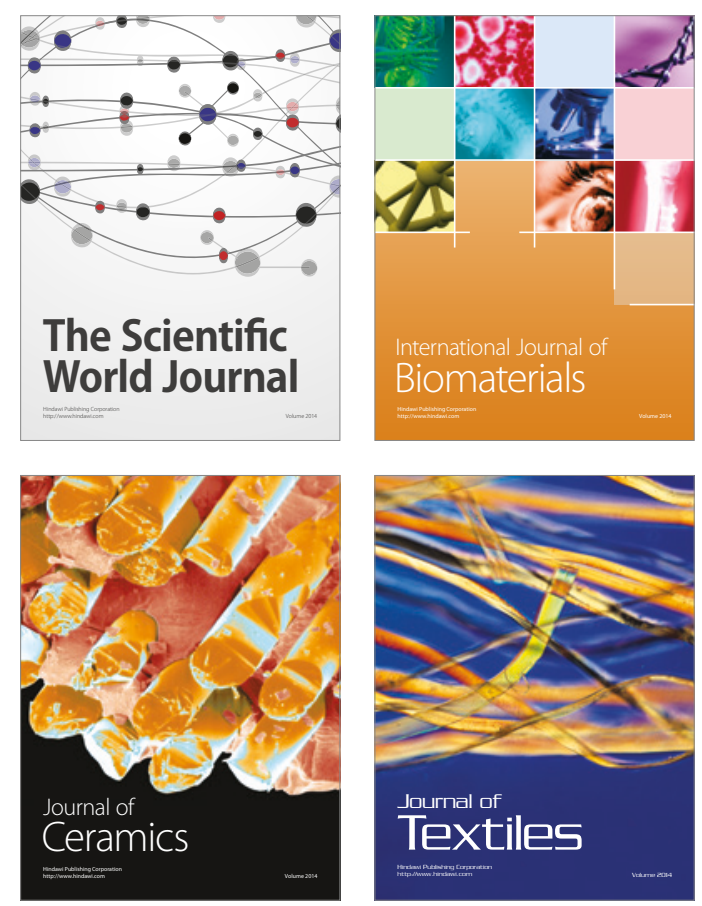